\title{
Personality Types and Coping Strategies as Correlates of Students' Academic Achievement
}

\author{
Saadu, Usman Tunde \\ Department of Early Childhood and Primary Education \\ Kwara State University, Malete. \\ Nigeria \\ Adedayo Adesokan \\ Department of Inclusive and Special Education \\ Kwara State University, Malete \\ Nigeria
}

\section{Doi:10.5901/jesr.2013.v3n5p17}

\begin{abstract}
This study examined how personality types and coping strategies employed by undergraduate students of Kwara State University could influence the academic achievement of the students. Descriptive survey was adopted for this study. Stratified random sampling was used to select 240 students across the six colleges. An instrument adapted from George Mayer (2001) was used to measure personality types and researcher designed questionnaire titled (Coping strategy questionnaire) was used to measure coping strategies employed by students during stress. A proforma was used to obtain Students present CGPA for 2012/2013 academic session to measure students' academic achievement. Two research questions were raised and answered with percentage while the research hypotheses were answered with t-test statistical analysis. The findings of the study revealed that students with personality $A$ achieved better academically than students with personality type $B$. Similarly students that employed problem coping strategies achieved better academically than students that employed emotional coping strategies. In the light of these findings, the researcher therefore recommended that enabling environment should be provided for students and skills that will promote problem coping strategies should be taught directly in the classroom at various institutions.
\end{abstract}

Keywords: Personality type; Coping Strategies; Academic Achievement

\section{Introduction}

This life activities are characterized by stress which an individual always find means of coping with them. The ability of individuals to function effectively in dealing with life challenges has been a topic of interest to psychologists (Phinney \& Hass, 2003). A major challenge for many of today's young people is the transition from high school to university. In general, studying at university is a stressful time for most students ( Tryphena \& Cecelia, 2007). This is the time when most adults are struggling with their new freedom and negotiating developmental tasks, focusing on interpersonal relationships and triggling that with academic concerns ( Beard, Elmore \& Lange, 1982). In addition, academic, social environment, and personality factors may contribute to adjustment to university life. According to Russsell and Petrie (1992) the adjustment to university stress can be organized according to three factors: academic performance, social adjustment and personal 
adjustment. This transition presents even more challenge to the international students (Tryphena \& Ceceha, 2007). This is due to the additional adjustment required to new environment, culture and language.

\section{Stress and Stress level}

Stress is now recognized as an inevitable aspect of life, but what makes the difference in human functioning is how people cope with it (Lazarus \& Folkman, 1984). Most people manage to maintain reasonable health and functioning under stressful conditions (Folkman, 1992). Stress is not a variable but rubric consisting of many variables and processes. Stress has been classified as a host of potentially unpleasant or dangerous events that include unavoidable pain excessive noise and fatigue under strenuous work conditions as well as more routine life changes (Mischel, 1986).

Stress could be categorized into different levels. The level of stress depends on how an individual copes with the given situation for example the readjustment, rating scale scores (Holmas \& Rahe, 1967; Holmes \& Masuda, 1974) offer a measure of current degree of stress. The scale indicates that the more change one is going through, the more stress one is experiencing. Generally, a significant but modest association has been found between degree of stress and physical illness. More stressful life events take somewhat greater physical and emotional toll on most, but not on all people (Rabskin \& Struening, 1976). Reactions to stress also depend on the individual's psychological environment. Individual's generally respond better to stress when they have social ties and supports, that is, close friends and groups to which they belong (Antonovsky, 1979). Individuals are able to cope better when they can share their experiences with others (Mischel, 1986). When individuals are members of a group to which they belong, they can receive emotional support, help with problems and even a boost to self-esteem (Cobb, 1976).

\section{Coping Styles}

Specific types of coping resources and strategies that deal with stress have been identified (Lazarus \& Felkman, 1984; Lazarus, 1993; Paker \& Endler, 1992). One way to define coping is a response to specific stressful situations (Moos \& Holahan, 2003). Coping is a dynamic process that fluctuates over time in response to changing demands and appraisals of the situation (Moos \& Holahan, 2003). Coping is a stabilizing factor that helps maintain psychological adjustment during stressful periods, coping efforts should be most helpful when there is a high level of stressors (Moos \& Holahan, 2003). A second way to define coping is as the changing of thoughts and actions to manage the external and internal demands for a stressful event ( Lazarus, 1991, 1999). Pierce \& Sarason (1996) presented a third way to define coping. For them the starting point is a specified event that involves personality characteristics, personal relationships and situational parameters.

According to Pierce, Sarason and Sarason (1996) individuals' coping styles are reflected in how they habitually construe and manage complex situations. In general, when personality characteristics, personal relationships and situational parameters come together to produce a robust coping style, individuals tend to exhibit the following characteristics. They tend to have more self-confidence; they tend to perceive that they have more control over stressful situations; they tend to be more persistent and assertive; and they tend to be more likely to expect success. These individuals will also tend to be less anxious, less depressed and tend to have fewer health problems (Heppner, 1988; Heppner \& Baker, 1997).

Coping is also determined by two constraints: personal and environmental. Personal constraints include psychological strengths/ deficits and internalized cultural values and beliefs that allow certain ways of behaving. Environmental constraints include demands that compete for the same resources that thwart coping efforts (Lazarus \& Folkman, 1984; Roth \& Cohen, 1986). The way an individual copes is influenced by his or her resources which include both health and energy (Lazarus \& Folkman, 1984), social support, material resources and existential beliefs, such as 
belief in God (Kim \& Duda, 2003). Those with these resources have been found to sustain stress better (Kim \& Duda, 2003). One consistent finding is that of the positive role of social support in helping an individual to cope with a stressful situation (Pierce, 1996). Social support could be viewed as a resource or as a coping response. As a resource, social support includes the availability of tangible help, guidance and emotional support. A coping response would include seeking help from others (Pierce, 1996).

Personality and coping are involved directly or indirectly in the production and maintenance of various kinds of adjustments (Sinyder \& Ford, 1987). Thus, personality traits could influence the types of coping style used. In terms of daily situations, and problems, that individuals face, judging coping by its effects on outcomes may do a disservice to the efforts that individuals make to cope with difficult, intractable and unrelenting conditions of life (Folkman, 1992). The presence of distress may indicate that adaptive coping processes are taking place.

There are various forms of coping style that could be used to deal with any particular stressor. Two general forms of coping styles are often distinguished in the coping literatures; Problem- focused coping and emotional-focused coping (as measured by the ways of coping scale, Folkman \& Lazarus, 1980).

Problem-focused coping involves management and alteration of the problem causing stress and may include learning about the problem, considering different viewpoints and possible options, and actively solving the problem. In the contrast, emotional-focused coping focuses on managing and alleviating the emotional distress that is associated with the problem and may include avoiding oneself from the problem, and minimizing the importance of the problems.

\section{Personality}

Personality traits are distinguishing qualities or characteristics of a person, that is, their readiness to think or act in a similar fashion in response to a variety of different stimuli or situations (Carver \& Scheiver, 2000). According to Gordon Allport's theory (1937), traits are determining tendencies or predisposition to which an individual respond. These traits are relatively general and enduring responses that produce fairly broad consistencies in behaviour. Allport (1937) believed that one's pattern of dispositions or personality structure is determined by a particular trait structure that is unique within that individual. Cattel (1965) defined a trait as the basic unit of study in personality as a "mental structure" inferred from behaviour, and as a fundamental construct that accounts for regularity and consistency of behaviour.

According to Eysenck (1970 cited in Eysenck \& Eysench, 1975) the main traits form two independent dimensions of personality. One reflects a changeable-unchangeable dimension, this is called extraversion-introversion dimension. The second reflects an emotional-non emotional or instability-stability dimension. This is called the neuroticism-normal dimension. These two dimensions have contributed more to a description of personality than any other set of two dimensions outside the personality field (Eysenck \& Eysenck 1969).

\section{Statement of the Problem}

Many factors have been responsible for poor academic achievement of students at various level of our educational system. Some of the factors identified are poor environment, lack of enthusiasm on the part of teachers among students and others. Similarly, previous researches have established that certain personality types have ability to cope with the academic stress than others and this make them to achieve better academically. This reason arouses the interest of the researcher to know the relationship that exists between the two independent variables; personality types and coping strategies and dependent variable academic achievement. 


\section{Purpose of the Study}

The main purpose of this study is to examine the relationship between personality types, coping strategies and academic achievement of undergraduate students of Kwara State University, Malete, Nigeria.

\section{Significance of the Study}

The finding of this study would be of immense assistance to all students in tertiary institutions to know the importance the personality types and its relationship with their academic achievement. Similarly, students would be able to identify coping strategies to stress so as to jettison those ones that affect their academic achievement and uphold those ones that are constructive and help in combating stress. The study would also assist the school administrators to know the importance of personality types and coping strategies and how it could determine academic achievement of the students in tertiary institutions. The study would assist book writers to write extensively on the personality types and coping strategies.

\section{Research Questions}

The following research questions were postulated and answered with percentage

1. What is the personality type of undergraduate students of Kwara State University, Malete Nigeria?

2. What are the Coping strategies employed by undergraduate students of Kwara State University, Malete?

\section{Research Hypotheses}

The following research hypotheses were generated and tested with t-test statistical analysis at 0.05 level of significance.

HO1: Personality types cannot significantly predict the academic achievement of undergraduate students of Kwara State University, Malete

HO2: Coping strategies cannot significantly predict the academic achievement of undergraduate students of Kwara state university, Malete

\section{Research Design}

This study is a Descriptive survey type. According to Akinboye (1985), descriptive survey research can be described as an empirical research type, which attempts to find the degree of association between operating variables in a particular population. Best and Khan (1989) describe it as the relationship between two or more paired variables or two or more sets of data.

The target population for this study is all the six existing colleges at Kwara state University, Malete. Simple random sampling technique was used to select two departments each across the six colleges in the University, making the total number of twelve (12) departments. Simple random samplig technique was used to select twenty (20) 300 level students in each department across the (12) departments which totaling 240 respondents that participated in this study. In a situation where the researcher could not find up to twenty 300 level students, 200 level students were picked to complete the required number. The reason for chosen 300 level students was based on the fact these students are moving to the final year in the university and it is presumed that students face much stress at their first year and last year in the university. Also, these students have spent more than two years in the university and they must have adopted series of coping strategies in coping with stress in the University. 
To obtain data from the respondents, two instruments were used. The first instrument was used to measure personality types of the students. The instrument was adapted from George Mayer personality scale (2001) The second instrument was a researcher designed questionnaire which was used to measure coping strategies employed by students. To establish the psychometric properties of the instruments, the researcher gave copies to the experts in the department for face and content validity. The corrections made were effected in the final copies of the instruments. To establish the reliability of the test, the researcher administered twenty (20) copies of the items to 300 level of an undergraduate students of University of Ilorin at the interval of three weeks. Test re-test method was used and Pearson Product Moment Correlation of Coefficient (PPMC) was used to correlate the first and second score. The score of $r=86$ was obtained. Also, the score of $r=78$ was obtained for the second test which is on coping strategies. A proforma was used to obtain the current CGPA of each student from the selected departments. The scores obtained were later correlated with the personality types and coping styles of the students. The CGPA of the students were converted to the grading system used by kwara state university.

\section{Results}

\subsection{Research Questions}

1) What is the personality type of undergraduate students at Kwara State University, Malete, Nigeria?

Table 1: Percentage showing personality types of the students

\begin{tabular}{ccc}
\hline Personality Type & Frequency & Percentage \\
\hline Type A & 117 & 48.8 \\
Type B & 123 & 51.2 \\
Total & 240 & 100 \\
\hline
\end{tabular}

Table 1 shows that out of 240 students sampled, 117 (48.8\%) have personality type A while 123 (51.25\%) have personality type $B$.

2) What is the coping strategy employed by students of Kwara State University, Malete , Nigeria?

Table 2: Percentage showing coping strategies employed by students of Kwara State University

\begin{tabular}{lcc}
\hline Coping Strategies & Frequency & Percentage \\
\hline Problem focused strategies & 127 & 52.9 \\
Emotional focused strategies & 113 & 47.1 \\
Total & 240 & 100 \\
\hline
\end{tabular}

Table 2 shows that out of 240 students sampled, 127 (52.9\%) employed problem strategies to solve their problems while $113(47.1 \%)$ employed emotional focus strategies to solve their problems.

\subsection{Hypotheses Testing}

Two hypotheses were postulated and tested with t-test statistic analysis at 0.05 level of significance. 
H01: Personality type cannot significantly influence the academic achievement of an undergraduate student of kwara students University, Malete, Nigeria

Table 3: T-test statistical analysis showing whether personality types influence students academic achievement

\begin{tabular}{ccccccccc}
\hline Personality types & N & Mean & $\begin{array}{c}\text { Std } \\
\text { Deviation }\end{array}$ & D.F & $\begin{array}{c}\text { Cal. t- } \\
\text { value }\end{array}$ & $\begin{array}{c}\text { Critical } \\
\text { t-value }\end{array}$ & Decision \\
\hline Academic & Type A & 117 & 7.1197 & 1.997 & & & & \\
Achievement & Type B & 123 & 5.9675 & 1.763 & 238 & $8.844^{*}$ & 1.960 & Sig. \\
& & 240 & 13.0872 & 3.76 & & & & \\
\hline
\end{tabular}

Sig. at 0.05 level of significant

Table 3 shows that the calculated t-value is 8.844 while the critical t-value is 1.960 , since the calculated t-value is greater than critical t-value, the null hypothesis is hereby rejected while the alternative hypothesis is upheld. The table also shows that students with personality type A achieved better academically than students with personality type B.

Hypothesis 2: Coping strategies cannot significantly influence the academic achievement of undergraduate students of kwara state university, Malete, Nigeria

Table 4: T-test statistical analysis showing whether coping strategies influences the academic achievement of an undergraduate students.

\begin{tabular}{ccccccccc}
\hline Coping strategies & N & Mean & $\begin{array}{c}\text { Std } \\
\text { Deviation }\end{array}$ & D.F & $\begin{array}{c}\text { Cal. t- } \\
\text { value }\end{array}$ & $\begin{array}{c}\text { Critical } \\
\text { t- } \\
\text { value }\end{array}$ & Decision \\
\hline $\begin{array}{c}\text { Problem } \\
\text { focused }\end{array}$ & 127 & 8.1969 & 1.8345 & & & & \\
Academic & $\begin{array}{c}\text { strategies } \\
\text { Achievement }\end{array}$ & & & & 238 & $12.705^{*}$ & 1.960 & Sig. \\
& $\begin{array}{c}\text { Emotional } \\
\text { focused } \\
\text { strategies }\end{array}$ & 113 & 6.6549 & 1.6265 & & & & \\
\hline
\end{tabular}

Sig. at 0.05 level of significant

Table 4 shows that the calculated t-value is 12.705 while critical t-value is 1.960 with 238 as the degree of freedom. Since the calculated t-value is greater than critical t-value, the null hypothesis is hereby rejected while the alternative hypothesis is accepted. The table also shows that students who employed problem focused strategies achieved better academically than students who employed emotional focused strategies.

\section{Discussion}

The first finding of this study revealed that students with personality type A achieved better academically than students with personality type B. According to Friedman and Rosenman (1974) personality type A students are always hostile, aggressive and impatient. He stated further that these qualities may account for better academic performance of the students. Similarly, students who employed problem focused strategies achieved better academically than students who employed emotional focused strategies. The finding of this study corroborates the work of Saranson and Saranson (1996) who asserted that students who employed problem focused strategies tend to have self confidence in their studies and have control over stressful situation. More often than not, they are more persistent and assertive. 


\section{Conclusion}

Personality type is a concept in psychology that needs to be examined by students and teachers because it will promote harmonious relationship among them. Also, coping strategies is an essential and crucial aspect of decision making, it therefore imperative that proper strategies should be employed.

\section{Recommendations}

Based on the findings of the study, the following recommendations were made:

$\checkmark$ Since there is no good or bad personality type, it is therefore essential that individuals should understand the personality type of his / her partner so as have smooth and harmonious relationship with him/her. In a similar vein, school environment should be conducive to accommodate various type of personality type.

$\checkmark$ Teachers should inculcate into students through direct teaching the skills to solve their problems and adopt proper problem solving strategies.

$\checkmark$ Government should always organize seminar and symposium to sensitize teachers on how to assist students to solve their problems.

$\checkmark$ Students should adopt problems focused strategies like tackling the problems directly instead of nursing it for a long time.

$\checkmark$ Functional counseling centers should be organized at various high institutions to cater for the needs and problems of students.

\section{References}

Allport, G.W. (1937). Personality; A psychological interpretation. Sydney, Australia; Holt, Rinehert and wiston

Antonovsky, A. (1979). Health stress and coping. San Fracisco; J ossey- Bass

Beard, S.S., Elmore, R.T., \& Lange, S. (1982). Assessment of students needs:Area of stress in the campus environment. Journal of college student development 23, 348-350

Cattel, R.B. (1965). The scientific analysis of personality. Baltimore: Penguin books

Carval, C.S. \& Scheier, M.F. (2000). Perspectives on personality $\left(4^{\text {th }}\right.$ edition) Needham Heights, M.A: Simon \& Schuster

Eysenck, S.B.G. \& Eysenck, H. j. (1970). A factor analytic study of the lie scale of the Junior Eysenck personality inventory. Personality 1, 3-10

Folkman, S. (1992). Making the case for coping. In Bruce N. carpenter (ed), personality Coping; Theory, research and application (pp 31-46). West port, conn: praeger publisher

Heppner, P. P. (1988). The problem solving inventory manual. Palo alto, CA; Consultant Psychologists press.

Hepper, P.P., \& Baker, P. (1997). Application of the problem solving inventory. Measurement and evaluation in counseling and development. 229-241

Holmas, T.H \& Rahe, R. H. (1967). The social re-adjustment rating scale. Journal of Psychosomatic research, 11, 213-218

Kim, M. S., \& Dauda, J. L. (2003). The coping process; cognitive appraisals of stress Coping strategies and coping effectiveness. The sport psychologist, 17, 406-425

Lazarus, R. S. (1991). Cognition and motivation in emotion. American psychologist 46, 325-367.

Lazarus, R.S. \& Folkman, S. (1984). Stress, appraisal and coping. New York; Springer

Moos, R .\& Holahan, C. (2003). Dispositional and contextual perspectives on coping:

Toward an integtrative framework. Journal of clinical psychology. 52 (12), 1387-1404

Mischel, W. (1986). Introduction to personality $\left(4^{\text {th }}\right.$ ed) Sydney, Ausralia: Hott, Rinehart and Winston

Phinney, J. S., \& Hass, K. (2003). The process of coping among ethnic minority first Generation college freshman; A narrative approach. J ournal of social psychology 143 (6), 707-727. 
Pierce, G.R., Sarason, I. G. \& Sarason, B. R. (1996). Coping and social support. In M Zeidner \& N. S. Endles (Eds), Handbook of coping: theory, research, applications (pp. 434-451). New York: wiley

Rabkin, J.G., \& Sruening, E.L. (1976). Life events, stress, and illness. Science, 194, 1031-1020

Snyder, C.R. \& McCrae, R,R. (2000). Sress and coping research: methodological Challenges, theoretical advances, and clinical applications. American psychologist 55 (6) 620-625.

Tryphena, J. T. \& Cecelia, W. (2011). The contribution of stress level, coping styles and Personality traits to international students academic performance. www.acu.edu.au 